\title{
Size of samples and homogenizers during classification of damaged soybeans
}

\author{
José R. Quirino ${ }^{1}$, Osvaldo Resende ${ }^{2}$, Natalia N. Fonseca², \\ Daniel E. C. de Oliveira ${ }^{3}$, Fatima C. Parizzi ${ }^{4} \&$ Tiago A. de Souza ${ }^{1}$
}

${ }^{1}$ Caramuru Alimentos S.A. Rio Verde, GO, Brasil. E-mail: zeronaldo@caramuru.com (Corresponding author) - ORCID: 0000-0003-4668-5546; tiago@caramuru.com - ORCID: 0000-0001-5739-7043

${ }^{2}$ Instituto Federal de Educação, Ciência e Tecnologia Goiano/Diretoria de Pesquisa e Pós-Graduação. Rio Verde, GO, Brasil. E-mail: osvresende@yahoo.com.br ORCID: 0000-0001-5089-7846; natnogueira1996@hotmail.com - ORCID: 0000-0002-3879-7743

${ }^{3}$ Instituto Federal de Educação, Ciência e Tecnologia Goiano. Iporá, GO, Brasil. E-mail: oliveira.d.e.c@gmail.com - ORCID: 0000-0002-3824-994X

${ }^{4}$ Ministério da Agricultura, Pecuária e Abastecimento. Brasília, DF, Brasil. E-mail: fatima.parizzi@agricultura.gov.br - ORCID: 0000-0001-5734-5315

\begin{abstract}
Grain quality determination involves important stages such as collection of the representative sample, homogenization, and dilution. The interrelation among sampling, homogenization, and working sample size is essential to the reliability of the information generated. Therefore, this work aimed to analyse the performance of mechanical homogenizers used in the commercialization of grains in Brazil, as a function of the size of the working sample masses during grain classification. The samples were homogenized and diluted in Boerner, 16:1 multichannel splitter, and 4:1 multichannel splitter until reaching masses of 0.025 , $0.050,0.075,0.100$ and $0.125 \mathrm{~kg}$ to determine the level of damaged grains. A $3 \times 4 \times 5$ factorial design was used, meaning three treatments relative to homogenizers (Boerner, 16:1 multichannel splitter, and 4:1 multichannel splitter), four dilutions $(4,8,12$ and $16 \%$ damaged grains), and five grain sample sizes $(0.025,0.050,0.075$, 0.100 and $0.125 \mathrm{~kg}$ ) with nine repetitions. The means were compared by Tukey test and to the original means of prepared samples $(4,8,12$, and $16 \%)$ by Student's t-test. Working samples can be utilized with masses between 0.025 and $0.125 \mathrm{~kg}$ to classify damaged soybeans grains. The devices Boerner, 16:1 multichannel splitter, and 4:1 multichannel splitter are similar in the reduction and homogenization of soybean samples for different levels of damaged grains and sample sizes.
\end{abstract}

Key words: dilution, sampling process, standardization

\section{Tamanhos de amostras e tipos de homogeneizadores na classificação física de grãos de soja}

RESUMO: A determinação da qualidade de grãos envolve etapas importantes como a retirada da amostra representativa do lote, homogeneização e diluição. A inter-relação entre a amostragem, homogeneização e o tamanho da amostra de trabalho é fundamental para a fidedignidade da informação gerada. Assim, objetivou-se analisar o desempenho de homogeneizadores mecânicos utilizados na comercialização de grãos no Brasil, em função do tamanho das massas de amostras de trabalho, durante a classificação de grãos de soja. As amostras foram homogeneizadas e diluídas nos equipamentos Boerner, quarteador multicanais 16:1 e quarteador multicanais 4:1 até se obter uma massa de amostras de trabalho com 0,025, 0,050, 0,075, 0,100 e 0,125 kg para determinação do nível de grãos avariados. Foi utilizado o delineamento fatorial $3 \times 4 \times$ 5 , sendo três tratamentos correspondentes aos homogeneizadores, quatro diluições $(4,8,12$ e $16 \%$ de grãos avariados) e cinco massas de grãos para trabalho, com nove repetições. As médias foram testadas entre si pelo teste Tukey e comparadas com as médias originais das amostras preparadas $(4,8,12$ e $16 \%)$ pelo teste t de Student. As amostras de trabalho podem ser utilizadas com massas entre 0,025 e $0,125 \mathrm{~kg}$ para a classificação de grãos de soja avariados. Os homogeneizadores e diluidores do tipo Boerner, quarteador multicanais 16:1 e quarteador multicanais 4:1 são semelhantes na redução e homogeneização de amostras de grãos de soja para diferentes níveis de grãos avariados e tamanhos de amostras.

Palavras-chave: diluição, processo de amostragem, padronização 


\section{INTRODUCTION}

Soybean is an oilseed crop of great importance for the global agroindustrial sector (Coradi et al., 2016) and grain quality is related to the management conditions prior to harvest (Huth et al., 2016) and during storage (Smaniotto et al., 2014).

Classification of grains is based on the comparison of the sample with a regulatory limit, a standard (Whitaker, 2006), which may be official or specific. Sampling efficiency is associated with the variation of the results generated and with the procedures adopted (Mallmann et al., 2013, 2014), which involve sample collection, equipment for homogenization and preparation of the working sample (Whitaker et al., 2011). The phase of homogenization is fundamental and should be conducted with equipment that ensure representativeness of the initial lot.

FAO (1993) describes that however representative the sample is, the final value will depend on the equipment's accuracy, as well as on the analysts' competence. Whitaker et al. (2011) claim that sample size interferes with the variability of the results, and larger the sample, the lower the variation of effects.

In the processing steps, the sample should be obtained by allowing all grains composing the lot to have the same chance of being sampled (Whitaker, 2003), ensuring higher randomness and lower interference in the operation.

Larger quantities of samples require the reduction in the amount of material, randomly, using homogenizers and splitters of samples (Fonseca, 2002). The normative instruction (NI) MAPA $n^{\circ} 11 / 2007$ (Brasil, 2007) establishes that the sample intended for classification needs to be homogenized and reduced by quartering.

Thus, the present study aimed to analyze the performance of mechanical homogenizers used in grain commercialization in Brazil as a function of the size of the working sample masses used to determine the quality of soybean grains.

\section{Material AND Methods}

The homogenizers were evaluated using damaged soybean grains. To simulate and identify the damaged grains, black soybean grains, with moisture content of $10.7 \%$ (w.b.) were used, which were added to the samples containing yellow grains with moisture content of $11.2 \%$ (w.b.), determined according to ASAE (2003).

Soybean bulk density was evaluated in a container of known volume $(1 \mathrm{~L})$, filled with grains of two coat colors in different lots, at a fixed falling height of $0.225 \mathrm{~m}$. After filling and weighing, bulk density was determined based on the ratio between mass $(\mathrm{kg})$ and volume $\left(\mathrm{m}^{3}\right)$ on a semi-analytical scale. The results were $751.7 \pm 1.90$ and $748.7 \pm 4.96 \mathrm{~kg} \mathrm{~m}^{-3}$ for yellow and black soybeans, respectively.

For the study, grain size uniformization and standardization were carried out by passing samples of soybean with black and yellow coat through sieves with 7.0-mm-diameter circular apertures. Soybean samples were previously prepared with levels of $4,8,12$ and $16 \%$ of damaged grains, represented by soybean with black coat.

The increments (simple samples) were prepared using proportions of black and yellow soybeans, which were inserted in a double-tube sampler with $2.10 \mathrm{~m}$ length and one opening stage. The sampler had 14 intakes with total capacity for $0.9 \mathrm{~kg}$ of soybean. For filling with the grains, the sampler was positioned vertically with closed intakes and the samples were inserted through the upper part proportionally, by alternating a quantity of mass of black soybean and another of yellow soybean.

The $4 \%$ level of damaged grains was obtained by inserting $0.036 \mathrm{~kg}$ of black soybean and $0.864 \mathrm{~kg}$ of yellow soybean in the sampler. These masses were divided at the respective proportions required for each dilution, into 14 parts, which correspond to the number of intakes in the sampler. The samples were inserted by alternately placing each one of the 14 parts until completing the total mass of $0.9 \mathrm{~kg}$.

To conduct the study, 792 samples of black and yellow soybeans were prepared, with 11 increments per replicate, in three replicates for each one of the three devices.

After that, for each dilution studied, the manuallyoperated double-tube sampler was unloaded directly into a container. Each of the samplers unloaded was considered as one increment (one sampling point). Each replicate had a sequence of 11 increments, to simulate 11 sampling points, as established in the NI MAPA $n^{\circ} 11 / 2007$ (Brasil, 2007), obtaining a composite sample of $9.9 \mathrm{~kg}$.

The level of damaged grains (black soybeans) was evaluated using working sample masses of $0.025,0.050,0.075,0.100$ and also the minimum mass of $0.125 \mathrm{~kg}$, as recommended by Brasil (2007). Then, the samples were homogenized and diluted in the devices: Boerner, 16:1 multichannel splitter and 4:1 multichannel splitter (Figure 1).

A. B.
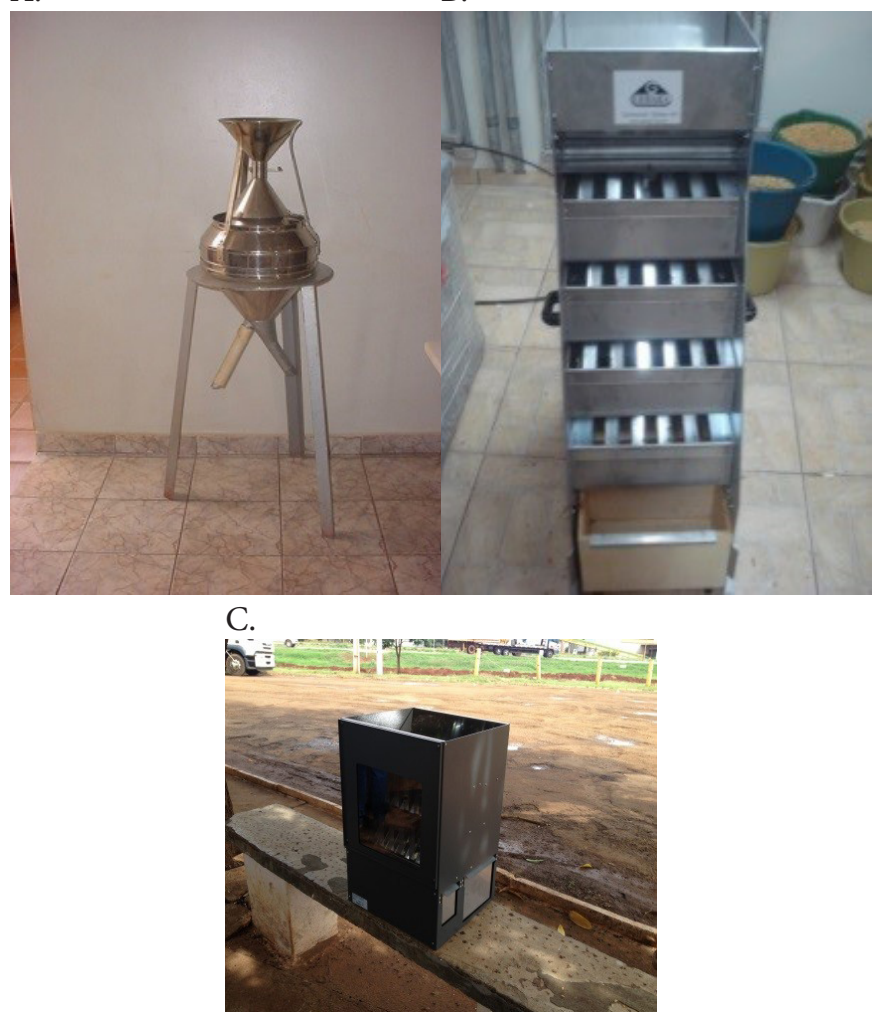

Figure 1. Illustration of the devices evaluated for homogenization and dilution of samples: Boerner (A); 16:1 multichannel splitter (B) and 4:1 multichannel splitter (C) 
The 16:1 multichannel splitter has the following dimensions: $0.32 \mathrm{~m}$ wide, $0.6 \mathrm{~m}$ long and $1.20 \mathrm{~m}$ high, consisting in the assembly of four small splitters, one below the other, from the discharge hopper of the device (Figure 1B). The first and third splitters have 12 channels (six for the sample and six for the reject) with mean width of $25.39 \mathrm{~mm}$, whereas the second and fourth splitters have 11 channels (six for the reject and five for the sample) with mean width of $25.30 \mathrm{~mm}$ and larger lateral channels, $39.18 \mathrm{~mm}$. As the discharge hopper opens, the product crosses the first splitter, one part of it is intended for the sample and the other part is discarded, and so on until the subdivision for the container of the working sample, and the other part, of larger volume, for the reject.

The 4:1 multichannel splitter is $0.45 \mathrm{~m}$ wide, $0.41 \mathrm{~m}$ long and $0.64 \mathrm{~m}$ high, and consists in the assembly of two smaller splitters (stages), one on top of the other. The first one is formed by 18 channels (nine for the sample with mean width of $25.25 \mathrm{~mm}$, plus a lateral channel with $16 \mathrm{~mm}$ width, and also nine channels for the reject with mean width of $25.25 \mathrm{~mm}$ ) (Figure 1C). This first splitter reduces and takes part of the sample to the reject and the sample passes through a second splitter with 17 channels (nine for the sample and eight for the reject), which also divides the grains, one part is discarded and the other part is used for the working sample. In this device, it is necessary to pass the grains more than once to reduce the working sample.

The Boerner has a hopper to pour the sample equipped with a valve that opens when the intention is to perform the operation of homogenization (Figure 1A). Grains pass through a funnel and randomly fall into an inverted cone which redistributes these grains along a circular frame with diameter of $0.36 \mathrm{~m}$, composed of a set of internal channels with $20.5 \mathrm{~mm}$ width and external channels with $24.7 \mathrm{~mm}$ width, which are directed to the internal and external funnels, and the samples are stored in containers.

Figure 2 presents the sequence of procedures for homogenization of the grains.

The obtained masses were compared with the previously prepared original sample. For the Boerner homogenizer and the 16:1 and 4:1 multichannel splitters, each sample was passed once for homogenization and then divided into three equal parts and placed in containers. These samples were passed in the homogenizer until obtaining the dilution to the working masses required for the experiment, which were 0.025, 0.050, $0.075,0.100$ and a minimum of $0.125 \mathrm{~kg}$, collecting three replicates for each device, each one with three subsamples identified. For the smaller masses, when it was necessary to complement the grain mass for dilutions in the 4:1 and 16:1 multichannel splitters, the samples were passed in the minisplitters located at the bottom of these devices through the lateral opening.

After homogenization and dilution, the working samples of each device, with masses of 0.025, 0.050, 0.075, 0.100 and $0.125 \mathrm{~kg}$ were analysed for the percentage of damaged grains (black coat).

Evaluations were conducted in completely randomized design with treatments in $3 \times 4 \times 5$ factorial arrangement, which consisted of three treatments corresponding to the homogenizers (Boerner, 16:1 multichannel splitter and 4:1 multichannel splitter), four dilutions $(4,8,12$ and $16 \%$ of damaged grains) and five grain masses $(0.025,0.050,0.075$, 0.100 and $0.125 \mathrm{~kg}$ ), in nine replicates.

The results were subjected to analysis of variance by F test, with all effects considered as fixed. Treatment means were compared to one another by Tukey test and to the original

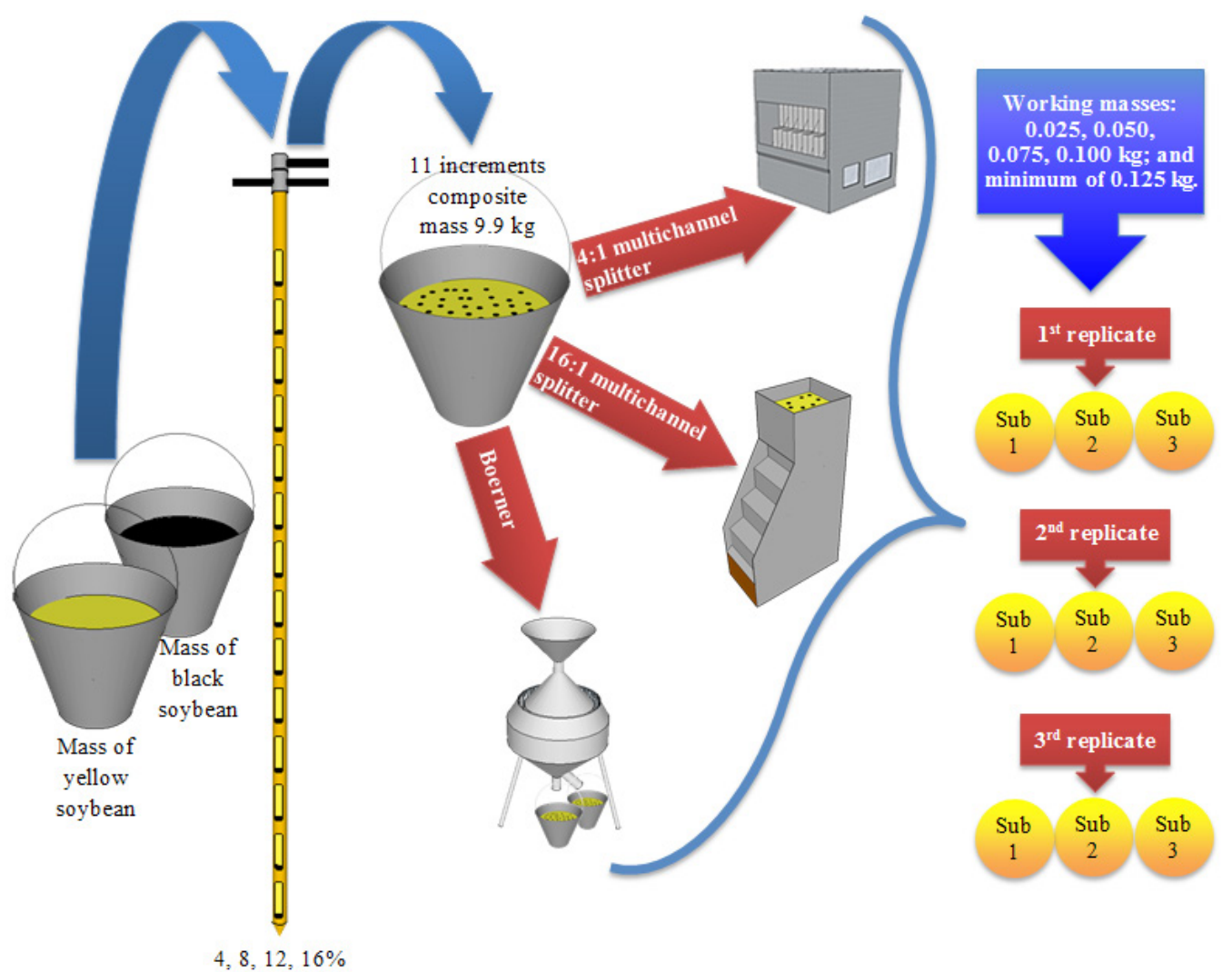

Figure 2. Schematic representation of the procedures of one replicate for homogenization of soybean grains 
means of the prepared samples $(4,8,12$ and $16 \%)$ by two-tailed Student's t-test.

\section{Results AND Discussion}

Brasil (2007) determines that for the classification of defects in soybean the sample should be reduced by quartering until obtaining a working sample which must weigh at least $0.125 \mathrm{~kg}$. However, in the present experiment, there was no difference between the studied working masses. Thus, it can be inferred that working sample masses below 0.125 up to $0.025 \mathrm{~kg}$ can be used to classify soybean grains without compromising the estimation of the original parameters of the lot, using the devices evaluated in this experiment.

There was no effect of the interaction between the factors mass of grains used for classification, dilution (four levels of damaged grains) and homogenizer devices (Boerner, 16:1 multichannel splitter and 4:1 multichannel splitter).

The results of the analysis of classification of the expected levels of damaged grains, regardless of the value of dilution $(4,8,12$ or $16 \%)$, demonstrated that there was no difference between the homogenizer devices (Table 1).

The devices Boerner, 16:1 multichannel splitter and 4:1 multichannel splitter did not differ from one another at all dilutions analysed (Table 1). However, the Boerner device behaved more uniformly, obtaining an mean deviation from the expected level of damaged grains of $0.64 \%$, followed by the $16: 1$ multichannel splitter with average deviation of $1.18 \%$, and by the $4: 1$ multichannel splitter with average deviation of $2.15 \%$, compared to the original means prepared.

Working samples weighing between 0.025 and $0.125 \mathrm{~kg}$ did not differ $(\mathrm{p} \leq 0.05)$ in the classification of damaged grains. Nevertheless, the coefficients of variation were equal to 14.36 , $13.47,11.10,9.70$ and 8.62 for working sample masses of 0.025 , $0.050,0.075,0.100$ and $0.125 \mathrm{~kg}$, respectively. There was a trend of reduction in the coefficients of variation among the replicates as the sample masses increased. Thus, the highest working masses used in the classification of damaged grains had the lowest variations, as reported by Whitaker et al. (2011).

According to Calori-Domingues et al. (2010), manual homogenization of the sample influences the variability of the coefficient of variation among subsamples from lots of fresh peanut for analysis of aflatoxins.

For all levels of damaged grains and all working masses used, the devices Boerner, 16:1 multichannel splitter and 4:1 multichannel splitter did not differ from the originally prepared means $(4,8,12$ and $16 \%)$ by t-test at 0.05 significance level (Table 2).

Table 1. Mean values of dilutions of working samples (4, 8, 12 and 16\%) homogenized in the devices Boerner, 16:1 multichannel splitter and 4:1 multichannel splitter

\begin{tabular}{|lcccc}
\hline \multirow{2}{*}{ Homogenizers } & \multicolumn{4}{c}{ Dilutions of working samples (\%) } \\
\cline { 2 - 5 } & $\mathbf{4}$ & $\mathbf{8}$ & $\mathbf{1 2}$ & $\mathbf{1 6}$ \\
\hline Boerner & $4.05 \mathrm{a}$ & $7.99 \mathrm{a}$ & $11.97 \mathrm{a}$ & $15.85 \mathrm{a}$ \\
$16: 1$ multichannel splitter & $4.08 \mathrm{a}$ & $8.01 \mathrm{a}$ & $12.25 \mathrm{a}$ & $16.08 \mathrm{a}$ \\
4:1 multichannel splitter & $4.19 \mathrm{a}$ & $8.06 \mathrm{a}$ & $12.29 \mathrm{a}$ & $15.89 \mathrm{a}$ \\
\hline
\end{tabular}

Means followed by the same letter in the columns do not differ at 0.01 significance level by Tukey test
Table 2. Probabilities associated with the two-tailed Student's $\mathrm{t}$-test ( $\mathrm{p}$-value) for the dilution of the working samples (4, 8,12 and 16\%) homogenized in the devices Boerner, 16:1 multichannel splitter and 4:1 multichannel splitter

\begin{tabular}{|c|c|c|c|c|c|}
\hline \multirow{2}{*}{ Homogenizers } & \multirow{2}{*}{$\begin{array}{c}\text { Masses } \\
(\mathrm{kg})\end{array}$} & \multicolumn{4}{|c|}{ Dilutions of working samples (\%) } \\
\hline & & 4 & 8 & 12 & 16 \\
\hline Boerner & & $0.992^{\text {ns }}$ & $0.886^{\mathrm{ns}}$ & $0.498^{\mathrm{ns}}$ & $0.454^{\mathrm{ns}}$ \\
\hline 16:1 Multichannel splitter & 0.025 & $0.605^{\mathrm{ns}}$ & $0.338^{\text {ns }}$ & $0.344^{\mathrm{ns}}$ & $0.789^{\mathrm{ns}}$ \\
\hline 4:1 Multichannel splitter & & 0.729 ns & $0.757^{\mathrm{ns}}$ & $0.289^{\mathrm{ns}}$ & $0.653^{\mathrm{ns}}$ \\
\hline Boerner & & $0.427^{\text {ns }}$ & $0.471^{\mathrm{ns}}$ & $0.585^{\mathrm{ns}}$ & $0.783^{\mathrm{ns}}$ \\
\hline 16:1 Multichannel splitter & 0.050 & $0.307^{\mathrm{ns}}$ & $0.534^{\text {ns }}$ & $0.350^{\mathrm{ns}}$ & $0.877^{\mathrm{ns}}$ \\
\hline 4:1 Multic & & $0.791^{\text {ns }}$ & $0.443^{\mathrm{ns}}$ & $0.332^{\mathrm{ns}}$ & $0.756^{\text {ns }}$ \\
\hline Boerner & & $0.601^{\text {ns }}$ & $0.5205^{\text {ns }}$ & $0.522^{\mathrm{ns}}$ & $0.083^{\mathrm{ns}}$ \\
\hline 16:1 Multichannel splitter & 0.075 & $0.752^{\mathrm{ns}}$ & $0.2091^{\mathrm{ns}}$ & $0.306^{\mathrm{ns}}$ & $0.629^{\text {ns }}$ \\
\hline 4:1 Multichannel splitter & & $0.164^{\mathrm{ns}}$ & $0.95^{\text {ns }}$ & $0.786^{\mathrm{ns}}$ & $0.334^{\mathrm{ns}}$ \\
\hline Boerner & & $0.566^{\mathrm{ns}}$ & $0.689^{\mathrm{ns}}$ & $0.943^{\mathrm{ns}}$ & $0.621^{\mathrm{ns}}$ \\
\hline 16:1 Multichannel splitter & 0.100 & $0.473^{\text {ns }}$ & 0.999 ns & $0.732^{\mathrm{ns}}$ & $0.361^{\mathrm{ns}}$ \\
\hline 4:1 Multichannel splitter & & $0.420^{\mathrm{ns}}$ & $0.991^{\mathrm{ns}}$ & $0.817^{\mathrm{ns}}$ & $0.974^{\mathrm{ns}}$ \\
\hline Boerner & & $0.123^{\text {ns }}$ & $0.687^{\mathrm{ns}}$ & $0.844^{\mathrm{ns}}$ & $0.168^{\mathrm{ns}}$ \\
\hline 16:1 Multichannel splitter & 0.125 & $0.997^{\mathrm{ns}}$ & $0.079^{\mathrm{ns}}$ & $0.756^{\mathrm{ns}}$ & $0.844^{\mathrm{ns}}$ \\
\hline 4:1 Multichannel splitter & & $0.166^{\mathrm{ns}}$ & $0.283^{\mathrm{ns}}$ & $0.666^{\mathrm{ns}}$ & $0.984^{\text {ns }}$ \\
\hline
\end{tabular}

For sample sizes from 0.025 to $0.125 \mathrm{~kg}$ at all dilutions of damaged grains $(4,8,12$ and $16 \%)$, the means of Boerner, 16:1 multichannel splitter and 4:1 multichannel splitter did not differ significantly from the originally prepared means by Student's t-test $(\mathrm{p} \leq 0.05)$ (Table 2$)$.

For the working masses of 0.100 and $0.125 \mathrm{~kg}$ at the damaged grain percentages of $4,8,12$ and $16 \%$, the devices Boerner, 16:1 multichannel splitter and 4:1 multichannel splitter did not differ ( $p \leq 0.05$ ). However, it is important to emphasize that the factor working sample should not be neglected, since it can compromise the impartial relationship of commercialization between the parts, especially in the reception of grains at storage units. At intermediate and terminal units in which the product, before being received by these units, has already been transferred during the filling of the warehouse and expedition in vehicles, barges and wagons, a greater homogenization of the grains is somehow promoted. This fact does not occur in the case of reception at storage and transfer units which receive the grains directly from production fields, i.e., product from the plantations, subject to variation of climate, soil, cultural practices and cultivars, showing high heterogeneity (Dawlal et al., 2012; Wagner \& Esbensen, 2014; Huth et al., 2016).

Hardin et al. (1965) conducted an experiment comparing the Gamet divider with the Boerner divider in alfalfa and ryegrass, using proportions of contaminants with dyed herb seeds, and reported that the Boerner divider has less chance of human error. It is also suggested that the Gamet divider, if correctly used, has results with accuracy close to that of the Boerner divider, but that the Boerner divider had more representative subsamples.

Several scientific studies have used and recommended the Boerner divider for homogenization and dilution of working samples (Doughtie Júnior, 1947; Fonseca, 2002; Al-Mahasneh \& Rababah, 2007), sample divider with inverted channels (sample quartering device) and Gamet divider (Fonseca, 2002; Calori-Domingues et al., 2010).

Sampling practices, therefore, should ensure procedures that involve satisfactory devices, capable of reliably evaluating grain quality, with lower variations from the original lot, 
to protect the quality at all stages: reception, storage and expedition. Mallmann et al. (2014), studying manual and automatic sampling in the preparation of samples for aflatoxin analysis, concluded that the sampling operation contributed with the highest variability, followed by the stages of sample preparation and analysis.

There have been cases of economic disputes between seller and buyer, not rarely due to inadequate or insufficient sampling procedures. These discrepancies cause errors, either in detecting impurities, defects, quantification of transgenic and mycotoxins, which are regulated by the contracts established in the soybean production chain (Wagner \& Esbensen, 2014).

Evaluation of grain quality losses depends on the capacity to make accurate predictions in a representative sample. No matter what the characteristics of the sample are, the results will not be relevant if the sample is not representative of the original product. Thus, the final result will depend exclusively on the accuracy of the instruments used and on the competence of the analysts, who should strive to achieve an acceptable level of accuracy at a reasonable cost for the analysis (FAO, 1993).

\section{Conclusions}

1. Working samples with masses between 0.025 and $0.125 \mathrm{~kg}$ can be used to classify damaged soybean grains.

2. The devices Boerner, 16:1 multichannel splitter and 4:1 multichannel splitter are similar in the reduction and homogenization of soybean grain samples for different levels of damaged grains and sample sizes.

\section{Acknowledgments}

To Instituto Federal Goiano (IF Goiano), Coordenação de Aperfeiçoamento de Pessoal de Nível Superior (CAPES, Brazil), Fundação de Amparo à Pesquisa do Estado de Goiás (FAPEG), Financiadora de Estudos e Projetos (FINEP, Brazil), Conselho Nacional de Desenvolvimento Científico e Tecnológico (CNPq, Brazil) and Caramuru S.A.

\section{Literature Cited}

Al-Mahasneh, A. M.; Rababah, T. M. Effect of moisture content on some physical properties of green wheat. Journal of Food Engineering, v.79, p.1467-1473, 2007. https://doi.org/10.1016/j. jfoodeng.2006.04.045

ASAE - American Society of Agricultural Engineering. Moisture measurement: Unground grain and seeds. St. Joseph: ASAE, 2003. 593p.

Brasil. Ministério da Agricultura, Pecuária e Abastecimento. Instrução normativa No. 11, de 15 de maio de 2007: Estabelece o regulamento técnico da soja. Brasília: Diário Oficial da República Federativa do Brasil, 2007. p.13-15. Seção 1

Calori-Domingues, M. A.; Rechdan, R. C.; Moretti, A.; Gloria, E. M. da; Zambello, I. V. Avaliação de procedimentos de preparo de amostra de amendoim in natura para análise de aflatoxinas. Química Nova, v.33, p.1490-1495, 2010. https://doi.org/10.1590/ S0100-40422010000700012
Coradi, P. C.; Fernandes, C. H. P.; Helmich, J. C.; Goneli, A. L. D. Effects of drying air temperature and grain initial moisture content on soybean quality [Glycine max (L.) Merrill]. Engenharia Agrícola, v.36, p.866-876, 2016. https://doi. org/10.1590/1809-4430-Eng.Agric.v36n5p866-876/2016

Dawlal, P.; Barros, E.; Marais, G. J. Evaluation of maize cultivars for their susceptibility towards mycotoxigenic fungi under storage conditions. Journal of Stored Products Research, v.48, p.114-119, 2012. https://doi.org/10.1016/j.jspr.2011.10.006

Doughtie Júnior, R. T. Sampling of cottonseed, soybeans and peanuts: Methods used and problems encountered. Journal of the American Oil Chemists' Society, v.24, p.335-340, 1947. https:// doi.org/10.1007/BF02643507

FAO - Food and Agriculture Organization. Prevención de pérdidas de alimentos poscosecha: Frutas, hortalizas, raíces y tuberculos. Roma: FAO, 1993. 183p.

Fonseca, H. Sampling plan for the analysis of aflatoxin in peanuts and corn: An update. Brazilian Journal of Microbiology, v.33, p.97105, 2002. https://doi.org/10.1590/S1517-83822002000200001

Hardin, E. E.; Copeland, L. O.; Knudson, L. A. A comparison of the relative effectiveness of the Boerner divider and several techniques of using the gamet precision divider. Proceedings of the Association of Official Seed Analysts, v.55, p.140-147, 1965.

Huth, C.; Mertz-Henning, L. M.; Lopes, S. J.; Tabaldi, L. A.; Rossato, L. V.; Krzyanowski, F. C.; Henning, F. A. Susceptibility to weathering damage and oxidative stress on soybean seeds with different lignin contents in the seed coat. Journal of Seed Science, v.38, p.296-304, 2016. https://doi.org/10.1590/2317$1545 \mathrm{v} 38 \mathrm{n} 4162115$

Mallmann, A. O.; Marchioro, A.; Oliveira, M. S.; Minetto, L.; Wovst, L. R. da S.; Rauber, R. H.; Dilkin, P.; Mallmann, C. A. Dois planos de amostragem para análise de fumonisinas em milho. Ciência Rural, v.43, p.551-558, 2013. https://doi.org/10.1590/ S0103-84782013000300029

Mallmann, A. O.; Marchioro, A.; Oliveira, M. S.; Rauber, R. H.; Dilkin, P.; Mallmann, C. A. Comparison of the efficiency between two sampling plans for aflatoxins analysis in maize. Brazilian Journal of Microbiology, v.45, p.35-42, 2014. https:// doi.org/10.1590/S1517-83822014000100006

Smaniotto, T. A. de S.; Resende, O.; Marçal, K. A. F.; Oliveira, D. E. C. de; Simon, G. A. Qualidade fisiológica das sementes de soja armazenadas em diferentes condições. Revista Brasileira de Engenharia Agrícola e Ambiental, v.18, p.446-453, 2014. https:// doi.org/10.1590/S1415-43662014000400013

Wagner, C.; Esbensen, K. H. A critical assessment of HGCA grain sample guide. TOS forum, v.2, p.16-21, 2014.

Whitaker, T. B. Standardisation of mycotoxin sampling procedures: An urgent necessity. Food Control, v.14, p.233-237, 2003. https:// doi.org/10.1016/S0956-7135(03)00012-4

Whitaker, T. B. Sampling foods mycotoxins. Foods Additives and Contaminants, v.23, p.50-61, 2006. https://doi. org/10.1080/02652030500241587

Whitaker, T. B.; Slate, A. B.; Doko, M. B.; Maestroni, B. M.; Cannavan, A. Sampling procedures to detect mycotoxins in agricultural commodities. New York: Springer Netherlands, 2011. 58p. https://doi.org/10.1007/978-90-481-9634-0 